\title{
EFFECTIVENESS OF INDICATION OF LEX MERCATORIA IN A CHOICE-OF-LAW CLAUSE IN INTERNATIONAL COMMERCIAL CONTRACTS
}

\begin{abstract}
The rule of unlimited choice of law for contractual obligations results from the rule of conflict of law autonomy of contracting parties' will, generally accepted in the international turnover. Concerns are raised by the matter of parties' indication of transnational rules of law or so-called ,soft law" acts, which will be applicable to the contract concluded within international commercial transaction. Being included in the "lex mercatoria" notion, they constitute - besides international legislation (uniform law) - one of the elements of the international commercial law. The practice of international trade requires application of legal solutions corresponding to its specific features, which are often not provided by national laws. Neutral solutions deriving from the business practice and understood by the turnover participants in the same way, constitute an alternative to the choice of a national law. The effectiveness of indication of lex mercatoria in a choice-of-law clause depends on whether a potential dispute resulting from the contract will be resolved by a national court or an arbitral tribunal. Unlike national courts, arbitral tribunals respect the parties' choice of lex mercatoria for the proper law of the contract. Due to a general character of rules of law, it is recommended to indicate in the choice-of-law clause a specific set of transnational rules prepared for transactions of international trade (such as UNIDROIT Principles of International Commercial Contracts). The effectiveness of such clauses is not in principle questioned by national courts in most countries in procedures of recognition and enforcement of foreign arbitral awards.
\end{abstract}

Keywords: lex mercatoria in a choice-of-law clause, international commercial contracts, international trade usages, principles of law and "soft law" acts, arbitration jurisdiction.

\section{INTRODUCTION}

Parties' possibility of indicating a national law of a given country (or even law binding on a part of its territory $)^{2}$ in a contract concluded within international commercial transaction, as the law applicable to the contract, does not raise concerns today. It results from the rule of (conflict of law) autonomy of contracting parties' will, which is generally accepted

\footnotetext{
${ }^{1}$ Natalia Szwajczak MSc, legal counsel; e-mail: kancelaria@szwajczak.pl. ORCID: 0000-0002-9501-5947.

Mgr Natalia Szwajczak, radca prawny; e-mail: kancelaria@szwajczak.pl. ORCID: 0000-0002-9501-5947.

2 Where a State comprises several territorial units, each of which has its own rules of law in respect of contractual obligations - see art. 22 Rome I Regulation of 2008 (see footnote 3).
} 
in the international turnover. It has also been confirmed by present conflict of law legislations ${ }^{3}$, including Rome I Regulation of $2008^{4}$, which - following the regulation stipulated in Rome Convention of $1980^{5}$ - sustained the rule of unlimited choice of law for contractual obligations enabling choice of law of any country, even not related in any manner with the legal relationship created by the contract. It is worth reminding that the rule of unlimited choice of law was proclaimed by the Resolution of International Law Institute (L'Insitut de Droit International) adopted during the 65th session of this Institute on 12 September 1991 in Basel: „The autonomy of the will of parties in international contracts between private persons". It was clearly stated in art. $2 \mathrm{sec} .1$ of this resolution that „The parties are free to choose the law applicable to their contract. They can agree on the application of every state law"6. The unlimited choice of law rule is stipulated also in art. 7 of Inter-American Convention on the Law Applicable to International Contracts (Mexico 17 March 19947, as well as in a number of regulations from the scope of international arbitration, including the Geneva Convention of $1961^{8}$, regulations of some courts of arbitration ${ }^{9}$ and UNCITRAL Arbitration Rules in their original version of $1976^{10}$.

On the other hand, the matter of parties' indication of transnational rules of law or socalled ,soft law” acts, as the rules which will be applicable to the international contract

${ }^{3}$ Ł. Żarnowiec, Wybór prawa jako metoda wskazania prawa właściwego dla umów obligacyjnych [in:] W. Popiołek (ed.), System Prawa Handlowego, t. 9: Międzynarodowe Prawo Handlowe, Warszawa 2013, SIP Legalis.

${ }^{4}$ Regulation (EC) No. 593/2008 of the European Parliament and of the Council of 17 June 2008 on the law applicable to contractual obligations (Rome I) (Official Journal of the EU L 2008 No. 177, p. 6).

5 Convention on the law applicable to contractual obligations opened for signature in Rome on 19 June 1980 (Official Journal of the EU C 2005 No. 169, p. 10).

6 Author's translation from: Rezolucja Instytutu Prawa Międzynarodowego (65 posiedzenie w Bazylei 1991): Autonomia woli stron w umowach międzynarodowych zawieranych między osobami prywatnymi, Problemy Prawne Handlu Zagranicznego 1993, Vol. 17, p. 162. On Basel Resolution see also: M. Pazdan, Rezolucja bazylejska z 1991 roku w sprawie autonomii woli $w$ zakresie umów zawieranych w międzynarodowym obrocie handlowym, ibidem, p. 124-130.

7 Text available on official website of OAS - Organisation of American States: http://www.oas.org/juridico/english/treaties/b-56.html.

${ }^{8}$ European Convention on International Commercial Arbitration of 1961 Done at Geneva, April 21, 1961 (Journal of Laws, No. 40, item 270).

${ }^{9}$ For instance of: The International Court of Arbitration at International Chamber of Commerce in Paris (ICC International Court of Arbitration), Court of Arbitration at the Polish Chamber of Commerce in Warsaw.

${ }^{10}$ In the light of art. 33 sec. 1 UNCITRAL Arbitration Rules (UNCITRAL - United Nations Commission on International Trade) in 1976 version parties could indicate the law as applicable for the merits of the dispute. In 2010 a modification has been made by changing in the relevant article the notion of ,the law" into „the rules of law" (at present art. $35 \mathrm{sec}$. 1 of the Rules), which will be mentioned further. On the relationship of the regulation concerning the applicable law in the revised Rules of 2010 and their original version of 1976 see P. Nowaczyk, A. Szumański, M. Szymańska, Regulamin Arbitrażowy UNCITRAL. Komentarz, Warszawa 2011, SIP Legalis. Texts of all versions of UNCITRAL Arbitration Rules are available on official website of UNCITRAL: http://www.uncitral.org/uncitral/en/uncitral_texts/arbitration/2010Arbitration_rules.html. More on the unlimited choice of law rule see: J. Poczobut, Zagadnienia kolizyjnoprawne $w$ międzynarodowym arbitrażu handlowym [in:] A. Szumański (ed.), System Prawa Handlowego, t. 8: Arbitraż Handlowy, Warszawa 2015, SIP Legalis. 
being concluded between them, still raises concerns ${ }^{11}$. Therefore, it may be worth having a closer look at their sources and considering whether in light of binding legal regulations, the scientific achievements and the practice of international turnover, they are really justified.

\section{LEX MERCATORIA}

Usages have had the decisive meaning in the practice of international trade for centuries. Their common application by merchants has led in the mediaeval Europe to the development of autonomous merchant law - lex mercatoria. The rules of this law had therefore the character of customary law which was binding until the appearance (in the eighteenth century) and the bloom (in the nineteenth and twentieth century) of domestic codifications of commercial law, as the French Code de Commerce (of 1807), or the German Handelsgesetzbuch (of 1897). Yet, the national regulations of commercial turnover, not being adjusted to the specific features of the international trade, met neither the requirements of this trade nor expectations of its participants ${ }^{12}$. As a result, on one hand, actions were undertaken aiming at unification of international trade relationships by means of international substantive-law conventions, which led to the occurrence of uniform law acts ${ }^{13}$. On the other hand, various private „,codifications” of trade usages applied in practice as well as model contracts and contract clauses and guidebooks on conclusion of contracts started to come into existence (so called ,soft law”). Furthermore, in the second half of the twentieth century, a theory of the new lex mercatoria - autonomous transnational commercial law was developed. According to this theory, international contracts may be subject to a transnational system of rules commonly accepted in international commercial turnover, the rules which have been gradually developed from the practice of this turnover.

Without prejudice to the confusion as to the notion of the ,lex mercatoria" ${ }^{14}$, it may be defined, in the most general way, as the whole of international trade usages constituting autonomous merchant law contrary to international legislation acts. „Lex mercatoria” viewed this way includes only rules of customary law and constitutes - next to international

${ }^{11}$ A presentation of standpoints in the doctrine in this scope describes B. Fuchs, Lex mercatoria w międzynarodowym obrocie handlowym, Kraków 2000 in chapter 4: Lex mercatoria jako statut kontraktowy?; see also J. Jakubowski, M. Tomaszewski, A. Tynel, A. Wiśniewski, Zarys międzynarodowego prawa handlowego, Warszawa 1983, p. 36-37.

${ }^{12}$ M. Pazdan, Pojęcie międzynarodowego prawa handlowego [in:] W. Popiołek (ed.), System Prawa Handlowego, t. $9 \ldots$

13 One of the most important legal acts included in uniform law is United Nations Convention on Contracts for the International Sale of Goods done in Vienna on 11 April 1980 (so-called Vienna Convention CISC) (Journal of Laws of 1997, No. 45, item 286 as amended).

${ }^{14}$ Various definitions of the „lex mercatoria” presented in the literature describes B. Fuchs [in:] Lex mercatoria..., p. 17-21; see also M. Pazdan, Pojęcie...; J. Jakubowski, M. Tomaszewski, A. Tynel, A. Wiśniewski, Zarys międzynarodowego..., p. 7 and subsequent; D. Mazur, Prawo właściwe w międzynarodowym arbitrażu handlowym, "Kwartalnik Prawa Prywatnego" 2003, issue 1, p. 140-145; K.P. Berger, The Creeping Codification of the New Lex Mercatoriam, 1999, parts published on Trans-Lex website: https://www.trans-lex.org/100600/_/berger-klaus-peter-thecreeping-codification-of-the-lex-mercatoria-the-hague-london-boston-1999/. 
legislation - one of the elements of the international commercial law ${ }^{15}$. Furthermore, without prejudice to various ways of classification of "soft law" in the taxonomy of the sources of international commercial law ${ }^{16}$, as well as discrepancies in views as to including general principles of law in the lex mercatoria ${ }^{17}$, for the sake of transparency of further analysis the notion of the lex mercatoria, for the needs of this work, shall include the two following categories of norms:

1) Principles of law, generally accepted and used in the international commercial turnover, such as for example: freedom of contract; obligation to respect the terms of contract (pacta sunt servanta), unless there is a substantial change of circumstances (rebus sic stantibus); performance of contracts in good faith; liability for not respecting good faith during negotiations (culpa in contrahendo); the rule that one cannot transfer more rights than actually has (nemo plus iuris transferre potest quam ipse habet); priority of a detailed provision over the general one (lex specialis derogat legi generali); the rule that one cannot take advantage of his own unlawful acts (nullus commodum capere potest de iniuria sua propria, ex iniuria non oritur ius) and many more. As a source of reference within this scope one may treat a particular set of these principles (amounting to 134 at the moment), which has been elaborated in a form of systematic specification together with numerous references to the scientific and judicial achievements, under the direction of K.P. Berger at the University of Cologne. It is available at on-line platform „Trans-Lex” (www.trans-lex.org), being operated by Center for Transnational Law (CENTRAL) at the Faculty of Law of the University of Cologne. It should be underlined that the initiator of this unique private codification of principles of transnational commercial law, K.P. Berger, defines this set as the "New Lex Mercatoria" 18.

${ }^{15}$ B. Fuchs, Lex mercatoria..., p. 56.

${ }^{16}$ See for example B. Fuchs, Lex mercatoria..., p. 57, where the author puts „,soft law” beyond the division of sources of international commercial law into international legislation and lex mercatoria, yet underlying that due to its "beyond-conventions" character ,soft law" is closer to lex mercatoria, and as a result includes soft law acts into sources of autonomous law. The same author in later publication acknowledges, within the context of soft law classification, relatively wide understanding of the notion of lex mercatoria as advisable (Lex mercatoria - pojęcie [in:] W. Popiołek (ed.), System Prawa Handlowego, t. 9... As per classification of the sources of the international commercial law see also: Źródta międzynarodowego prawa handlowego [in:] W. Popiołek (ed.), System Prawa Handlowego, t. 9...

${ }_{17}$ See B. Fuchs, Lex mercatoria..., p. 105 and the literature mentioned there - according to the author, the opponent of including the general principles of law in autonomous merchant law is for example A. Szumański, who draws attention to the general character of principles of law requiring in every case to be specified, in contradiction to the lex mercatoria rules which provide detailed resolutions. See also D. Mazur, Prawo wtaściwe.., p. 140-145.

18 www.trans-lex.org/the-lex-mercatoria-and-the-translex-principles_ID8. More on Trans-Lex principles: E. Rott-Pietrzyk, Zasady Międzynarodowego Prawa Handlowego TRANS LEX (TRANSLEX Principles) [in:] W. Popiołek (ed.) System Prawa Handlowego, t. 9... Some authors use the term „lex mercatoria” for identification principles of law only - so for example the authors of a study: International Chamber of Commerce Policy and Business Practices Developing neutral legal standards for international contracts. A-national rules as the applicable law in international commercial contracts with particular reference to the ICC Model Contracts, prepared by the Task Force chaired by F. Bortolotti and F.S. Toni di Cigoli, p. 10 text available on ICC website: 
2) „Soft law” that is acts prepared by various international organisations or institutions, which - being the law beyond conventions - derive their binding force from the will of contracting parties. What should be included here are various ,private" codifications of trade usages, model law acts (standard contracts, general conditions) and guidebooks on conclusion of contracts, which facilitate formulating the contents of a contract being concluded between the parties, specify the rights and obligations during performance of the contract and in settlement of disputes. Only as an example one may include in "soft law" acts INCOTERMS $®$ rules elaborated by International Chamber of Commerce ICC) with its seat in Paris, constituting a set of codified trade usages in the scope of co-called delivery base which define mutual obligations of parties to a sale contract connected with the delivery of goods (division of costs, obligations and risk $)^{19}$. ICC prepared also, among others, uniform rules for contract guarantee $\mathrm{s}^{20}$, uniform customs and practice for documentary credits ${ }^{21}$, uniform rules for collections ${ }^{22}$, uniform rules for forfaiting ${ }^{23}$. Another example are UNIDROIT Principles of International Commercial Contracts ${ }^{24}$, elaborated by International Institute for the Unification of Private Law with its seat in Rome, as well as Principles of European Contract Law ${ }^{25}$, prepared by a commission of Prof. O. Lando (so called the „Lando Commission”). As model law acts one may indicate a number of model contracts and model contract clauses prepared for instance by $\mathrm{ICC}^{26}$, or typical contracts and general conditions prepared by the United Nations Economic Commission for Europe ${ }^{27}$.

http://store.iccwbo.org/content/uploaded/pdf/Developing_Neutral_Legal_Standards_Int_Contracts.pdf.

19 The first version of INCOTERMS $®$ was published in 1936, subsequent versions date from 1953, $1967,1974,1980,1990,2000$, and the last one from 2010. At present, the next version is under preparation and it is to be launched in 2020. See ICC website: https://iccwbo.org/resources-forbusiness/incoterms-rules/incoterms-rules-history/.

${ }^{20}$ ICC Uniform Rules for Contract Guarantees (ICC Publication No. 325E) edition of 1978.

${ }^{21}$ ICC Uniform Customs and Practice for Documentary Credits UCP 600 (ICC Publication No. 600LE) - edition of 2007.

${ }^{22}$ ICC Uniform Rules for Collections (ICC Publication No. 522E) - edition of 1995.

${ }^{23}$ ICC Uniform Rules for Forfaiting URF 800 (ICC Publication No. 800E - edition of 2012.

${ }^{24}$ UNIDROIT Principles of International Commercial Contracts were announced for the first time in 1994, subsequent versions date from 2004, 2010, the last version of 2016 is available on official website of UNIDROIT: https://www.unidroit.org/instruments/commercial-contracts/unidroit-principles-2016

25 Principles of European Contract Law (PECL), text available on Trans-Lex website: https://www.trans-lex.org/400200.

${ }^{26}$ For instance: ICC Model International Sale Contract - ICC Publication No. 738E, edition of 2013 (in Polish version edition of 2004 MIH Publication No. 556), ICC Model Contract on Distributorship - ICC Publication No. 776E, ICC Model Contract Commercial Agency - ICC Publication No. 766E, ICC Model International Franchising Contract - ICC Publication No. 712E, ICC Force Majeure Clause, ICC Hardship Clause - ICC Publication No. 650 (available also in Polish version). See more on ICC website: http://store.iccwbo.org/model-contracts.

27 On UNECE works in this scope see J. Jakubowski, M. Tomaszewski, A. Tynel, A. Wiśniewski, Zarys międzynarodowego..., p. 27-28 and J. Hermanowski, Handel zagraniczny. Poradnik, Zielona Góra 2009, p. 10. 


\section{APPLICATION OF LEX MERCATORIA IN THE PRACTICE OF INTERNATIONAL TRADE}

The ,soft law" acts play an important role in the practice of international trade, because as accepted standards responding to its needs, they are used all over the world by the participants of this trade. Referring by parties to the rules of law happens in practice perhaps not so frequently, but has also its supporters. The practice of international trade shows therefore that the choice of these principles and regulations is attractive for the turnover participants.

In case when parties negotiating an international contract cannot agree on the choice of the law of either of them as the law applicable to the contract, it often happens that, seeking for neutral solutions, the parties submit the contract to the law of a third country (for example Swiss, English or German law). Though at the stage of the contract conclusion such a solution may seem to be optimal (both parties are in the same position as they choose the law which is not familiar to each of them), at the stage of the contract performance or in case of dispute it may appear that some provisions of the contract are inconsistent with the chosen law or the contract contains gaps the fulfillment of which in accordance with the chosen law gives results totally different than those expected by the parties. This is because in practice it rarely happens that, due to substantial costs and needed time, the parties before the contract conclusion - assuming that they themselves do not know the chosen law of the third country - submitted the draft contract for legal opinion in light of this law. Eventually the potential controversy will generate additional costs of legal services and the solution of the problem may turn out to be time-consuming.

What is more, national laws regulate in principle internal legal relationships and as such they may prove to be not adjusted to the specific features of international trade (as regards for instance distributorship, franchising or joint ventures contracts). It may happen that such laws will offer, in a given situation, unclear solutions (based more on principles established by courts than on specific legal provisions), which will constitute the basis for potential discrepancies. ${ }^{28}$ Therefore, a domestic law will not always be this one, which complies with expectations and interests of the parties to the fullest possible extent. Thus, application of a particular transnational set of rules generally accepted in international commercial turnover, which derive from the business practice and are understood by the turnover participants in the same way, may prove to be the optimal solution.

The parties may certainly indicate, which in practice happens quite often, a specific regulation of the uniform law (for example the Vienna Convention CISC) as the applicable law. However, the legal consequences of such indication will primarily depend on whether such a regulation is a part of a national law applicable according to the conflict-of-law rules (then the parties will remain within the framework of the given domestic law), or it is not (only then the choice of the given regulation as the law applicable to the contract may produce $^{29}$ effects involving a conflict of law, otherwise the contract being submitted to the law of the given country which did not ratify the given convention). Furthermore, it must be

\footnotetext{
${ }^{28}$ More on disadvantages of domestic law in the practice of international turnover [in:] B. Fuchs, Lex mercatoria..., p. 13-17, and in: ICC Developing neutral..., p. 17-18.

${ }^{29}$ Depending on settlement of the potential dispute by a national court or an arbitral tribunal - which will be discussed further.
} 
remembered that there is a relatively small number of international conventions which introduced the uniform law ${ }^{30}$, hence they concern quite small scope of contract types and, what is more, are not binding in all countries of the world but only in these ones which ratified them (for example Great Britain has not ratified the Vienna Convention CISC until today). Finally, because of the fact that the scope of a particular convention never covers all aspects of a given legal relationship, but usually only issues specific for the given type of a contract, more general issues must be decided in accordance with the applicable national law. Due to an autonomous character of the conventions introducing the uniform law, which they keep despite their incorporation to the national law, it is raised in the literature that these conventions should be interpreted and supplemented by autonomous transnational rules of law they derive from ${ }^{31}$.

The application of a transnational set of specific rules, such as the UNIDROIT Principles of International Commercial Contracts or the Principles of European Contract Law, in an international contract may take place in two ways. One of them is to include them in the contents of contract either by means of their literal repetition, even rewriting to the text of the contract (incorporation), or by means of referring to them (interpolation). In such a way they will have substantive law effects (so-called "incorporation of foreign law") and they are binding as contract clauses within the parties' freedom of contract. The limits of their binding force are determined by mandatory provisions of substantive law (ius cogens) which is applicable according to the conflict-of-law rules. The contract remains then in the framework of the specific national law. The second way is to indicate the aforementioned rules as the law applicable to a contract, which constitutes choice of law (in the sense of conflict-of-law rules) to be appraised in light of the applicable private international law ${ }^{32}$.

The model contracts are used in practice by means of their application as prepared standards. In case when they consist not only of the detailed part to be supplemented by parties, but of the general part containing complete substantial law provisions of the given legal relationship as well ${ }^{33}$, the parties include the "soft law" regulation in their contract (by

30 Apart from the Vienna convention cisc see unidroit convention on international financial leasing (Ottawa, 28 may 1988) text available on official website of unidroit: https://www.unidroit.org/instruments/leasing/convention-leasing; unidroit convention on international factoring (Ottawa, 28 may 1988) text available on official website of unidroit: https://www.unidroit.org/instruments/factoring; convention on agency in the international sale of goods (Geneva, 17 february 1983) text available on official website of unidroit: https://www.unidroit.org/instruments/agency.

${ }^{31}$ See for example UNIDROIT Model Clauses for the Use of the UNIDROIT Principles of International Commercial Contracts, Rome 2013, text available on official website of UNIDROIT: https://www.unidroit.org/english/principles/modelclauses2013/modelclauses-2013.pdf, p. 16; and M. Jagielska, Konwencja wiedeńska [w:] W. Popiołek (ed.), System Prawa Handlowego, t. 9...

${ }^{32}$ More on the distinction between choice of law (in the sense of conflict-of-law rules) and ,incorporation of foreign law", including the used terminology, see M. Pazdan, Materialnoprawne wskazanie a kolizyjnoprawny wybór prawa, Problemy Prawne Handlu Zagranicznego 1995, V. 18; J. Jakubowski, M. Tomaszewski, A. Tynel, A. Wiśniewski, Zarys międzynarodowego..., p. 31; M. Czepelak, Autonomia woli w prawie prywatnym międzynarodowym Unii Europejskiej, Warszawa 2015, p. 340-342; see also E. Rott-Pietrzyk, Interpretacja umów w prawie modelowym $i$ wspólnym europejskim prawie sprzedaży (CESL), Warszawa 2013, SIP Legalis and M. Łolik, Wspótczesne prawo kontraktów - wybrane zagadnienia, Warszawa 2014, SIP Legalis.

${ }^{33}$ For example this is the way in which ICC Model International Sale Contract is prepared: it consists of part A - detailed provisions and part B - general provisions (referring besides to Vienna Convention CISC). 
means of incorporation or interpolation). Another thing is that model contracts, in order to produce effects involving a conflict of law, often contain choice-of-law clauses which frequently as an option - enable the parties to choose rules of law or a specific regulation of "soft law", as for instance the UNIDROIT Principles of International Commercial Contracts, the Principles of European Contract Law or other "a-national" rules indicated by the parties $^{34}$.

The effectiveness of indication of lex mercatoria in a choice-of-law clause must be analysed on a ground of its application (or non-application) by a court resolving a dispute which resulted from the concluded contract. This is because the choice of law to be applicable to the contract has effects not only between the parties themselves, but first of all - if it is to fulfill its role - it should be effective before the court that is competent for a dispute settlement. In this respect a distinction between a national (domestic) court and an arbitral tribunal appears to be essential.

\section{LEX MERCATORIA IN ARBITRATION JURISDICTION}

National (domestic) courts will apply the provisions of its own private international law (lex fori) for the assessment of a contractual choice-of-law clause. Because of the fact that, according to the present standards of conflict of law legislations, only a state law (not rules of law $)^{35}$, can be the subject of a choice of law, it is very unlikely that a domestic court will accept the effectiveness (in the sense of conflict-of-law rules) of a contractual choice-oflaw clause indicating general principles of law or soft law regulations as the law applicable to the contract. It is only possible that the domestic court will view such a clause as being in the nature of an "incorporation of foreign law" and, by treating it as the parties' reference to the indicated transnational rules, will apply them within the framework of the legal system applicable on the basis of the private international law rules of the forum ${ }^{36}$. In case when potential disputes are to be submitted to domestic courts, including such clauses in contracts is not therefore recommended.

The matter looks differently in arbitration jurisdiction, which unquestionable advantages (among others in the context of proceedings speed, the degree of procedural formalization, award enforcement) are particularly valuable for the participants of the commercial international turnover who eagerly take the possibility of excluding the competence of national courts in favor of arbitral tribunal. A particular way in which arbitration courts treat the parties autonomy is their additional card, which has its reflection in the sphere of assessment what norms should be applicable to the merits of the dispute.

As it was mentioned in the introduction, regulations of the arbitration jurisdiction (both international legislation acts and the rules of arbitration courts) recognize the rule of unlimited choice of law. Furthermore, differently from the private international law rules, many of these regulations provide for the possibility of indication by the parties the rules of law

\footnotetext{
${ }^{34}$ See for example ICC model contracts (footnote 25), which include optional choice-of-law clauses referring among others to rules of law together with the UNIDROIT Principles of International Commercial Contracts.

${ }^{35}$ Doubts in this scope are not left by art. $3 \mathrm{sec} .1$ of the „Rome I” Regulation of 2008: „A contract shall be governed by the law chosen by the parties".

${ }^{36}$ So for example J. Pazdan, Czy można wytaczyć umowe spod prawa?, „Państwo i Prawo” 2005, No. 10, p. $14-16$
} 
as applicable to the merits of the dispute. For instance, art. $28 \mathrm{sec} .1,1^{\text {st }}$ sentence of the UNCITRAL Model Law on International Commercial Arbitration of 1985 reads as follows: "The arbitral tribunal shall decide the dispute in accordance with such rules of law as are chosen by the parties as applicable to the substance of the dispute" 37 . A provision of a similar wording is included in UNCITRAL Arbitration Rules (in the version revised in 2010) ${ }^{38}$, as well as in the Arbitration Rules of the ICC International Court of Arbitration ${ }^{39}$. Moreover, in the Basel Resolution of 1991, which excludes the possibility of choice of norms other than a domestic law, a different solution was stipulated in the preamble for arbitration proceedings ${ }^{40}$.

Additionally, while private international laws exclude the possibility of choice of lex mercatoria as the "lex contractus" (i.e. the law applicable to the assessment of the rights and obligations arising from the contract), "national rules governing arbitration tend to recognize the freedom of the parties to have their disputes decided in accordance with general principles of law" ${ }^{\prime 1}$. As an example, art. $1194 \S 1$ of the Polish Code of civil procedure ${ }^{42}$ may be indicated: „The arbitral tribunal shall decide the dispute in accordance with the law applicable for the given relationship, and if the parties have expressly authorized it to do so - in accordance with the general rules of law or ex aequo et bono"43. Another example is art. 1511. the first sentence of the French Code of civil procedure ${ }^{44}$ : „The arbitral tribunal shall decide the dispute in accordance with the rules of law chosen by the parties or, in case of no choice, in accordance with those which it determines to be appropriate" 45 .

Finally, the fact that a clause indicating regulations of lex mercatoria as the law governing the contract would not be considered by a national court as a valid choice of law, does not mean that this court will not recognize and enforce an arbitral award which applied such regulations. The scope of control of foreign arbitral awards exercised by national courts as indicated in art. V of the New York Convention ${ }^{46}$, which has been ratified by 159 countries so $\mathrm{far}^{47}$, excludes the possibility of judging the merits of the case by a domestic court. In result, arbitral awards which applied norms of lex mercatoria (general principles of law,

37 Text of UNCITRAL Model Law is available on official website of UNCITRAL: http://www. uncitral.org/pdf/english/texts/arbitration/ml-arb/07-86998_Ebook.pdf.

38 Art. $35 \mathrm{sec} .1$ the first sentence. See footnote 9.

39 Art. 21 sec. 1 the first sentence. The 2017 Arbitration Rules version is available on ICC website: https://cdn.iccwbo.org/content/uploads/sites/3/2017/01/ICC-2017-Arbitration-and-2014-Mediation-Rules-english-version.pdf.pdf.

${ }^{40}$ See footnote 5.

${ }^{41}$ ICC Developing neutral..., p. 23.

42 Code of civil procedure of 17 November 1974 (consolidated text Journal of Laws of 2018 r., item 1360 as amended).

43 Translation of the author.

${ }^{44}$ Decree No. 2011-48 of 13 January 2011, text available on a public legal service website Legifrance: https://www.legifrance.gouv.fr/eli/decret/2011/1/13/2011-48/jo/texte.

45 Translation of the author.

${ }^{46}$ Convention on the Recognition and Enforcement of Foreign Arbitral Awards, done on 10 June 1958 (Journal of Laws of 1962, No. 9, item 41).

47 The actual status of the Convention available on official website of UNCITRAL: http://www. uncitral.org/uncitral/en/uncitral_texts/arbitration/NYConvention_status.html. 
transnational regulations of the customary merchant law) are in principle recognized and enforced by domestic courts ${ }^{48}$.

Together with the development of the theory of new lex mercatoria in the second half of the twentieth century we encounter arbitral awards which applied general principles of law recognized in international trade, in subsequent decisions already defined as lex mercatoria. In practice of arbitration it has been recognized with time that parties may choose lex mercatoria instead of national law for the proper law of the contract and arbitral tribunal will accept such a choice. ${ }^{49}$ It is worth underlining here that, due to a general character of rules of law, it is recommended to clearly indicate in the choice-of-law clause a specific set of transnational rules prepared for transactions of international trade (such as the above mentioned UNIDROIT Principles of International Commercial Contracts). Thus, model choice-of-law clauses prepared by ICC usually join a few elements - for instance principles of law generally recognized in international trade, trade usages and the UNIDROIT Principles of International Commercial Contracts, at the same time defining their hierarchy ${ }^{50}$. On the other hand, various ways of application of the UNIDROIT Principles of International Commercial Contracts in commercial contracts and dispute resolution practice are reflected in Model Clauses prepared by UNIDROIT ${ }^{51}$. What is interesting, in case of choice of a specific act of international legislation (for example Vienna Convention CISC) as the applicable law, when due to the lack of ratification there are no objective requirements for its application, the parties achieve twofold result. The first one will be the choice of law in the sense of conflict of law rules (the convention will govern their contract although it has not been incorporated to the domestic law as there was no ratification). Secondly, if the parties stipulate this in the clause, generally recognized principles of law (lex mercatoria) will apply for interpretation or supplementation with respect to the issues not covered by the chosen convention (which, in case the convention is applied as a part of domestic law, would be submitted to this law $)^{52}$.

Summarizing, arbitral tribunals respect the parties' decision to submit their contract to the regulations of lex mercatoria, which may be taken not only at the stage of contract conclusion by means of choosing these regulations for the proper law of the contract (which in practice happens rather rarely), but also at the stage of a dispute by means of authorizing the arbitral tribunal to decide the dispute according to these regulations (which is a more frequent practice). And though clauses indicating regulations other than a domestic law as

\footnotetext{
${ }^{48}$ More on this subject see ICC Developing neutral..., p. 21-22 and judicial decisions referred there. See however D. Mazur, Prawo wtaściwe..., p. 140-145, who draws attention to the necessity of earlier ascertainment of the parties as to the potential refusal of recognition and enforcement of arbitral award in a legal system that does not recognize lex mercatoria.

${ }^{49}$ ICC Developing neutral..., p. 6, 8 and arbitral awards referred there; see also T. Wiśniewski, M. Hauser-Morel, Wyrok, zasady wyrokowania i inne sposoby zakonczenia postęowania arbitrażowego [in:] A. Szumański (ed.), System Prawa Handlowego, t. 8...

${ }^{50}$ More on this subject see ICC Developing neutral..., p. 15-16.

${ }^{51}$ UNIDROIT Model Clauses..., see footnote 30.

${ }^{52}$ See UNIDROIT Principles Model Clause No. 3(a): ,This contract shall be governed by the United Nations Convention on Contracts for the International Sale of Goods (CISC) interpreted and supplemented by the UNIDROIT Principles of International Commercial Contracts (2016)", ibidem, p. $16-19$.
} 
the applicable law are very rarely included in contracts, as the ICC statistics of 2017 show $^{53}$, the effectiveness of such clauses in arbitration proceedings is established these days.

\section{SUMMARY}

Sceptics with reference to indication of lex mercatoria in a choice-of-law clause raise a number of arguments to the detriment of such solution. Passing over, in this place, the fact that national courts will not accept such clauses as a valid choice of law, it is raised particularly that, due to their general character, the principles of law leave much latitude to the discretion of the arbitrators and by this do not warrant enough certainty and foreseeability of the possible outcome of the dispute, which is so significant for the international trade participants. In fact, in many cases the choice of a national law and submitting possible disputes to domestic courts may be a good solution (for instance in case of a standard single sale contract concluded between parties from countries which ratified the Vienna Convention CISC). However, the business practice gives rise to a number of complicated transactions, for which it is hard to find satisfactory solutions in national laws and what is more the choice of law is often the issue that blocks negotiations. In such situations it is worth considering as an alternative option whether or not to choose the neutral rules of lex mercatoria, which - as they derive from the practice of international trade - will better suit the parties' expectations. And, in order to guarantee greater accuracy and foreseeability of the chosen legal solutions, the parties may - notwithstanding indication of rules of law - choose a specific set of principles of "soft law" prepared especially for international transactions (for example the UNIDROIT Principles of International Commercial Contracts). When a contract including such a choice-of-law clause is submitted to arbitration jurisdiction, it is possible to achieve in many cases at least the same predictability of potential outcomes of the disputes as in case of a choice of a national law. One must also bear in mind that a judicial proceeding, even in case when a national court applies its own national law, always involves a certain degree of uncertainty as to the final outcome of the dispute.

As the practice of arbitration and noticeable trends in the literature show, the principles of an autonomous, transnational merchant law gain greater meaning as possible "lex contractus" in international commercial contracts. Clauses indicating lex mercatoria as an applicable law for such contracts are at present respected by arbitral tribunals, and furthermore their effectiveness is not in principle questioned by national courts in most countries in procedures of recognition and enforcement of foreign arbitral awards. Due to undoubted advantages of applying the lex meractoria rules in international trade, one should support the aim of recognition by national courts the contractual choice-of-law clauses indicating such rules as a valid choice of law.

\footnotetext{
53 "In $87 \%$ of the disputes referred to ICC Arbitration in 2017, parties included a choice-of-law clause in their contracts", out of which in $99 \%$ of cases the parties chose national laws, and only in $1 \%$ other regulations - including: Vienna Convention CISC (5 contracts), EU legislation (5 contracts), the UNIDROIT Principles of International Commercial Contracts (1 contract), lex mercatoria (1 contract), ,customary international law” (1 contract), „UNCITRAL Law” (1 contract), ICC Incoterms (1 contract) [in:] ICC Dispute Resolution Bulletin, 2018, issue 2, p. 61.
} 


\section{REFERENCES}

1. Czepelak M., Autonomia woli w prawie prywatnym międzynarodowym Unii Europejskiej, Warszawa 2015.

2. Fuchs B., Lex mercatoria - pojęcie [in:] W. Popiołek (ed.), System Prawa Handlowego, t. 9: Międzynarodowe Prawo Handlowe, Warszawa 2013, SIP Legalis.

3. Fuchs B., Lex mercatoria w międzynarodowym obrocie handlowym, Kraków 2000.

4. Hermanowski J., Handel zagraniczny. Poradnik, Zielona Góra 2009.

5. ICC Dispute Resolution Bulletin, 2018, issue 2.

6. Jagielska M., Konwencja wiedeńska w: W. Popiołek (ed.) System Prawa Handlowego, t. 9: Międzynarodowe Prawo Handlowe, Warszawa 2013, SIP Legalis.

7. Jakubowski J., Tomaszewski M., Tynel A., Wiśniewski A., Zarys międzynarodowego prawa handlowego, Warszawa 1983.

8. Łolik M., Współczesne prawo kontraktów - wybrane zagadnienia, Warszawa 2014, SIP Legalis.

9. Mazur D., Prawo wtaściwe w międzynarodowym arbitrażu handlowym, Kwartalnik Prawa Prywatnego 2003, issue 1.

10. Nowaczyk P., Szumański A., Szymańska M., Regulamin Arbitrażowy UNCITRAL. Komentarz, Warszawa 2011, SIP Legalis.

11. Pazdan J., Czy można wyłaczyć umowę spod prawa?, „Państwo i Prawo” 2005, No. 10.

12. Pazdan M., Materialnoprawne wskazanie a kolizyjnoprawny wybór prawa, Problemy Prawne Handlu Zagranicznego 1995, V. 18.

13. Pazdan M., Pojęcie międzynarodowego prawa handlowego [in:] W. Popiołek (ed.) System Prawa Handlowego, t. 9: Międzynarodowe Prawo Handlowe, Warszawa 2013, SIP Legalis.

14. Pazdan M., Rezolucja bazylejska z 1991 roku w sprawie autonomii woli w zakresie umów zawieranych w międzynarodowym obrocie handlowym, „Problemy Prawne Handlu Zagranicznego" 1993, Vol. 17.

15. Poczobut J., Zagadnienia kolizyjnoprawne w międzynarodowym arbitrażu handlowym [in:] A. Szumański (ed.), System Prawa Handlowego, t. 8: Arbitraż Handlowy, Warszawa 2015, SIP Legalis.

16. Rezolucja Instytutu Prawa Międzynarodowego (65. posiedzenie w Bazylei 1991): Autonomia woli stron $w$ umowach międzynarodowych zawieranych między osobami prywatnymi, „Problemy Prawne Handlu Zagranicznego” 1993, Vol. 17.

17. Rott-Pietrzyk E., Interpretacja umów w prawie modelowym i wspólnym europejskim prawie sprzedazy (CESL), Warszawa 2013, SIP Legalis.

18. Rott-Pietrzyk E., Zasady Międzynarodowego Prawa Handlowego TRANS LEX (TRANSLEX Principles) [in:] W. Popiołek (ed.), System Prawa Handlowego, t. 9: Międzynarodowe Prawo Handlowe, Warszawa 2013, SIP Legalis.

19. Wiśniewski T., Hauser-Morel H., Wyrok, zasady wyrokowania i inne sposoby zakończenia postępowania arbitrażowego [in:] A. Szumański (ed.) System Prawa Handlowego, t. 8: Arbitraż Handlowy, Warszawa 2015, SIP Legalis.

20. Źródła międzynarodowego prawa handlowego [in:] W. Popiołek (ed.) System Prawa Handlowego, t. 9: Międzynarodowe Prawo Handlowe, Warszawa 2013, SIP Legalis.

21. Żarnowiec Ł., Wybór prawa jako metoda wskazania prawa wtaściwego dla umów obligacyjnych [in:] W. Popiołek (ed.), System Prawa Handlowego, t. 9: Międzynarodowe Prawo Handlowe, Warszawa 2013, SIP Legalis. 


\section{LEGAL ACTS}

1. Code of civil procedure of 17 November 1974 (consolidated text Journal of Laws of 2018 r., item 1360 as amended).

2. Convention on the law applicable to contractual obligations opened for signature in Rome on 19 June 1980 (Official Journal of the EU C 2005 No. 169, p. 10).

3. Convention on the Recognition and Enforcement of Foreign Arbitral Awards, done on 10 June 1958 (Journal of Laws of 1962, No. 9, item 41).

4. European Convention on International Commercial Arbitration of 1961 Done at Geneva, April 21, 1961 (Journal of Laws of, No. 40, item 270).

5. Regulation (EC) No 593/2008 of the European Parliament and of the Council of 17 June 2008 on the law applicable to contractual obligations (Rome I) (Official Journal of the EU L 2008 No. 177, p. 6).

6. United Nations Convention on Contracts for the International Sale of Goods done in Vienna on 11 April 1980 (so-called Vienna Convention CISC) (Journal of Laws of 1997, No. 45, item 286 as amended).

\section{INTERNET SOURCES}

1. http://www.oas.org/juridico/english/treaties/b-56.html.

2. http://www.uncitral.org/uncitral/en/uncitral_texts/arbitration/2010Arbitration_rules.html.

3. Berger K.P., The Creeping Codification of the New Lex Mercatoriam, 1999, parts published on Trans-Lex website: https://www.trans-lex.org/100600/_/berger-klaus-peter-the-creeping-codification-of-the-lex-mercatoria-the-hague-london-boston-1999/.

4. www.trans-lex.org/the-lex-mercatoria-and-the-translex-principles_ID8.

5. International Chamber of Commerce Policy and Business Practices Developing neutral legal standards for international contracts. A-national rules as the applicable law in international commercial contracts with particular reference to the ICC Model Contracts, prepared by the Task Force chaired by F. Bortolotti and F.S. Toni di Cigoli, p. 10 text available on ICC website: http://store.iccwbo.org/content/uploaded/pdf/Developing_Neutral_Legal_ Standards_Int_Contracts.pdf.

6. https://iccwbo.org/resources-for-business/incoterms-rules/incoterms-rules-history/.

7. https://www.unidroit.org/instruments/commercial-contracts/unidroit-principles-2016.

8. https://www.trans-lex.org/400200.

9. http://store.iccwbo.org/model-contracts.

10. https://www.unidroit.org/instruments/leasing/convention-leasing.

11. https://www.unidroit.org/instruments/factoring.

12. https://www.unidroit.org/instruments/agency.

13. https://www.unidroit.org/english/principles/modelclauses2013/modelclauses-2013.pdf.

14. http://www.uncitral.org/pdf/english/texts/arbitration/ml-arb/07-86998_Ebook.pdf.

15. https://cdn.iccwbo.org/content/uploads/sites/3/2017/01/ICC-2017-Arbitration-and-2014Mediation-Rules-english-version.pdf.pdf.

16. https://www.legifrance.gouv.fr/eli/decret/2011/1/13/2011-48/jo/texte.

17. http://www.uncitral.org/uncitral/en/uncitral_texts/arbitration/NYConvention_status.html. 


\section{SKUTECZNOŚĆ WSKAZANIA LEX MERCATORIA W KLAUZULI WYBORU PRAWA W MIĘDZYNARODOWYCH UMOWACH HANDLOWYCH}

Z kolizyjnoprawnej autonomii woli stron umowy, powszechnie akceptowanej w obrocie międzynarodowym, wynika zasada nieograniczonego wyboru prawa dla zobowiązań umownych. Wątpliwości budzi kwestia wskazywania przez strony na ponadnarodowe zasady prawa lub akty tzw. „soft law”, które będą właściwe dla umowy zawieranej w ramach transakcji handlu międzynarodowego. Zaliczane do pojęcia „lex mercatoria” stanowią - obok legislacji międzynarodowej (uniform law) - jeden z członów międzynarodowego prawa handlowego. Praktyka handlu międzynarodowego wymaga stosowania rozwiązań prawnych odpowiadających jego specyfice, których prawo krajowe często nie dostarcza. Rozwiązania neutralne, wywodzące się z praktyki biznesowej i rozumiane przez uczestników obrotu w jednakowy sposób, stanowią alternatywę w stosunku do wyboru prawa krajowego. Skuteczność wskazania lex mercatoria w klauzuli wyboru prawa zależy od tego, czy ewentualny spór wynikający z umowy będzie rozpatrywany przez sąd krajowy czy arbitrażowy. Inaczej niż sądy krajowe, trybunały arbitrażowe respektują dokonany przez strony wybór lex mercatoria na statut kontraktowy umowy. Z uwagi na ogólny charakter zasad prawa zalecane jest wskazanie w klauzuli wyboru prawa konkretnego zbioru ponadnarodowych zasad opracowanych z myślą o transakcjach handlu międzynarodowego (takich jak np. Zasady Międzynarodowych Kontraktów Handlowych UNIDROIT). Skuteczność takich klauzul z reguły nie jest podważana przez sądy krajowe $\mathrm{w}$ większości państw $\mathrm{w}$ ramach procedur uznawania i wykonywania zagranicznych orzeczeń arbitrażowych.

Słowa kluczowe: lex mercatoria w klauzuli wyboru prawa, międzynarodowe umowy handlowe, międzynarodowe zwyczaje handlowe, zasady prawa i akty „soft law”, sądownictwo arbitrażowe.

DOI: 10.7862/rz.2018.mmr.56

Tekst złożono do redakcji: listopad 2018 r.

Tekst przyjęto do druku: grudzień 2018 r. 